\title{
Propensity to Travel After Covid
}

Voyager après le Covid

Frédéric Thomas

\section{Q OpenEdition}

\section{Journals}

\section{Electronic version}

URL: https://journals.openedition.org/tourisme/4139

DOI: $10.4000 /$ tourisme 4139

ISSN: 2492-7503

\section{Publisher}

Association Mondes du tourisme

\section{Electronic reference}

Frédéric Thomas, "Propensity to Travel After Covid", Mondes du Tourisme [Online], 20 | 2021, Online since 15 December 2021, connection on 17 December 2021. URL: http://journals.openedition.org/ tourisme/4139; DOI: https://doi.org/10.4000/tourisme.4139

This text was automatically generated on 17 December 2021.

\section{(c) (1) () $\ominus$}

Mondes du tourisme est mis à disposition selon les termes de la licence Creative Commons Attribution - Pas d'Utilisation Commerciale - Pas de Modification 4.0 International. 


\title{
Propensity to Travel After Covid
}

\author{
Voyager après le Covid
}

\author{
Frédéric Thomas
}

\section{Introduction}

1 The Covid-19 pandemic has severely impacted the tourism sector with a $74 \%$ drop in international arrivals in 2020, and it went from bad to worse in early 2021, declining by $85 \%$ between January and May 2021 when compared to the same period of 2019, according to the latest data from the World Tourism Organisation (UNWTO). Destinations around the world welcomed 1 billion fewer international arrivals in 2020 than the previous year. While many efforts have been made to revive the sector and assist tourism entrepreneurs and operators, the issue of travel propensity, while central, has not been addressed until several months after the pandemic began. Most studies have focused on the impacts (Gössling et al., 2021; Sigala, 2020; Uğur and Akbiyık, 2020) and response strategies to the challenges posed by the pandemic (Gombault, 2021) before turning, after a few months, to the perception of travel risk (Gallego and Font, 2021). Among the factors explaining this trend is the logical and priority need to take stock of the situation before considering appropriate solutions for recovery. This observation of the transition from over-tourism in many destinations to the total absence of tourism (Koh, 2020) has highlighted the need to make tourism more 'sustainable' (Ioannides and Gyimóthy, 2020) or to use the pandemic as a transformative opportunity (Mair, 2020).

2 Focusing on recovery strategies is to some extent an assumption that individuals will not change their behaviour and continue to travel. However, it seemed necessary to examine the perception of individuals of different nationalities as to their propensity or willingness to be a tourist (Kožić et al., 2016), with regard to 1) their financial situation due to the predicted economic crisis, 2) their sense of safety with regard to travelling to urban or mass tourism destinations and 3) whether or not their perception of travel is changing towards more responsible products as expected. Will international tourism change considerably as many academics and international organisations, such 
as UNWTO, see the need for a different form of tourism, one that is more respectful of the people visited and of nature? Or is the ambition for a more sustainable form of tourism more a matter of so-called social desirability bias? A phenomenon that can be observed when respondents answer what they think they should do and not what they would actually do. In our case, they perceive, at the time of the study, the continuity of tourism, as it exists, as socially unacceptable or undesirable.

3 This short paper therefore aims to share some insights not only into the propensity of individuals to travel post Covid, but also into their perceptions of desired destinations and forms of tourism. Indirectly, this raises the question of the need for more regulations if the aim is to transform tourism into a sustainable industry. After presenting the methodology, the article describes the results of the survey and, on the basis of these results, proposes a discussion on the existing contradictions that emerge when conducting a questionnaire in times of crisis ${ }^{1}$.

\section{Literature review}

4 In a review of international research on tourism and Covid-19, Gombault et al. (2020) concluded that researchers considered that the Covid-19 crisis will not revolutionise the tourism industry overnight, but it will lead to operational and strategic changes at several levels. But if there is one area that has fallen victim to a revolution - perhaps a temporary one-, it is scientific research. Indeed, the pandemic has revolutionised scientific research with more than 87,000 scientific papers on the coronavirus from the beginning of the pandemic until February 2021 (Cai et al., 2020). Almost the entire global scientific community has focused its attention on this issue alone. With regard to tourism itself, Yang et al. (2021), for example, presented a review of early publications on Covid-19 and tourism, including 249 papers revealing five key themes: (1) psychological effects and behaviour; (2) responses, strategies and resilience; (3) sustainable futures; (4) impact monitoring, assessment and prediction; and (5) technology adoption. Through a selection process using keywords such as Covid-19 and tourism development, Casado-Aranda et al. (2021) obtained a result of 1,303 papers published between 1 December 2019 and 31 March 2021. According to the authors, the academics with the largest contributions on this matter were primarily from Canadian, Australian, and Chinese universities.

Currently, numerous tourism journals still issue calls for papers to better understand the implications of Covid-19 for tourists, businesses and organisations, and to offer insight into recovery strategies. But uncertainty remains. The pandemic is still ongoing, and not all countries have the same access to vaccinations, leading to questions about the consequences of reopening borders. Although some countries now consider that they must learn to live with the virus (Australia, New Zealand, etc.), they generally belong to the category of those who can meet the public health needs of their population.

Thus, according to Gombault et al. (2020), the crisis could radically transform mobilities on a global scale. For tourism to exist, individuals must be willing to travel. Propensity to travel, loosely defined as willingness of a person to be a tourist, is one of the most fundamental concepts of tourism research (Kožić et al., 2016). Indeed, the first tourists generally preceded tourism investments and policies. In a globalised economy, it is therefore interesting to see that the focus on the impact of Covid-19 has been primarily 
on economic aspects and not on the propensity to travel. Examination of the released dates of the publications cited in Yang et al. (2021) article confirms that mobilityrelated issues, such as behavioural issues, came later than those related to monitoring, impact assessment and prediction, and responses, strategies and resilience in the articles on the subject.

In the same vein, Casado-Aranda et al. (2021) observed that only two of the top 10 cited Covid-related articles (Sigala, 2020; Wen et al., 2020) refer to travel patterns. Extensive and important research on the propensity to travel has nevertheless already been carried out, particularly with regard to key factors in the propensity to travel, such as socio-demographic factors (Zahirović et al., 2021). Thus, while traveling decisions imply that the use of significant logistic and financial resources no longer remain available for the family, Covid-19 has recently appeared as a new factor impacting the propensity to travel.

8 Interestingly, however, Hu et al. (2021) consider that while most existing studies have focused on examining the effects of pandemics from a macro and/or meso perspective, little is known about how the dynamics of pandemic situations change the perceptions and expectations of individual travellers over time. What is known is that common findings from previous research have resulted in a negative correlation between tourists' risk perceptions and behavioural intentions (Godovykh et al., 2021). For the same authors, previous explanations of health risk perceptions include factors such as people's knowledge and understanding of the disease, personal experience, trust and cultural values, as well as demographic, cultural and personality characteristics. Therefore, during an outbreak, travellers decide to avoid the affected area, but quickly resume their travel behaviour when they feel the risk is low.

9 A study of the SARS outbreak in Japan (2003), reviewed by Cooper (2006), concluded that tourists' avoidance of SARS-infected areas led to a reduction of over half the number of outbound Japanese travellers. Thus, in the aftermath of the Covid-19 crisis, governments will play a crucial role in mitigating the negative perception that foreigners may have of their country. In particular, the issue of vaccination levels now seems to play a major role in risk perception, but the fact that certain countries are significantly further ahead in vaccination rates, which in turn affects the confidence of the end consumers, is creating new inequalities and preventing global tourism from recovering across the board (Tourism Review, 2021).

\section{Methodology}

We designed a post Covid-19 travel propensity questionnaire, translated into 16 languages, to capture individuals' feelings about their desire to travel after the pandemic. It was shared online on both Google and wjx (Chinese) platforms and through professional and academic tourism networks. Therefore, an unknown proportion of respondents were people working or studying in the field of tourism, which can be seen as introducing a bias. However, a large volume of responses helps to balance this possibility, as the more widely the questionnaire is distributed, the more diverse the audience of respondents.

The questionnaire consisted of six questions referring to the respondents' propensity to travel and the likelihood of changing their behaviour after Covid. There was no attempt to have an internal consistency for all respondents between the questions, as 
they measure different characteristics, namely, willingness to travel, ability to travel, distance of travel in the context of a health crisis, desired impact of future travel, type of destinations visited, and perception of destinations internationally in terms of health risks. For each question, respondents were offered choices within a so-called Likert attitude scale of 1 to 5 . With a score of 1 being "strongly disagree", 3 being "undecided" and 5 being "strongly agree". Finally, they were asked about their perception of the different regions of the world in terms of their level of public health risk and therefore the likelihood of travelling there.

In order to analyse the results, Likert scale data being considered as ordinal, each item has a rank that is higher or lower than others, but the exact differences between the items aren't evenly spaced or clearly defined. In two or more independent groups, when the outcome variable is ordinal (agreement here) and the independent variable is nominal (age, origin, gender), we cannot compare the mean values between groups. However, we can compare the medians between the groups. In this article, we are therefore using non-parametric tests to determine whether there are any statistically significant differences between the medians by region of origin, gender or age. The descriptive analysis of the results is first carried out using the nationality of the respondents, before statistical tests are carried out on the basis of geographical regions of origin.

\section{Results}

13 A total of 1,764 questionnaires were collected online over 30 days, from 18 April to 18 May 2020. The main respondents were from European countries (794), followed by Asia (605), America (168), Oceania and Pacific (99) and Africa and the Middle East (98). The French accounted for $29 \%$ of respondents, followed by the Chinese (15\%), Iranians (7\%), Colombians (5\%) and Australians (5\%). Almost twice as many women as men responded to the survey (64.9\% of respondents were women, compared to $34.5 \%$ of men). However, the ratio of men to women is reversed for respondents from Iran and South Korea.

Table 1. Top 10 nationalities and countries of residence

\begin{tabular}{|l|l|l|l|l|}
\hline & \multicolumn{2}{|l|}{ Nationality } & \multicolumn{2}{l|}{ Country of residence } \\
\hline & $\#$ & $\%$ & $\#$ & $\%$ \\
\hline French & 513 & $29 \%$ & 557 & $31.6 \%$ \\
\hline Chinese & 273 & $15.4 \%$ & 239 & $13.5 \%$ \\
\hline Iranian & 128 & $7.2 \%$ & 112 & $6.3 \%$ \\
\hline Colombian & 89 & $5 \%$ & 90 & $5.1 \%$ \\
\hline Australian & 82 & $4.6 \%$ & 97 & $5.5 \%$ \\
\hline Korean & 77 & $4.3 \%$ & 68 & $3.9 \%$ \\
\hline
\end{tabular}




\begin{tabular}{|l|l|l|l|l|}
\hline Vietnamese & 66 & $3.7 \%$ & 56 & $3.2 \%$ \\
\hline American & 47 & $1.3 \%$ & 46 & $2.6 \%$ \\
\hline Thai & 36 & $2.0 \%$ & 49 & $2.8 \%$ \\
\hline German & 32 & $1.8 \%$ & 19 & $1.1 \%$ \\
\hline Others & 421 & $23.9 \%$ & 431 & $24.4 \%$ \\
\hline
\end{tabular}

14 Table 2 shows the gender and age distribution of the different groups of nationalities. The proportion of women was smaller in the Africa and Middle-East group mainly due to the Iranian respondents. The average age of respondents was between 25 and 34 years, although differences appear between nationality groups with respondents generally older in East Asia (55-64) and Oceania and the Pacific (45-54).

Table 2. Gender and age bracket of respondents for the main group of nationalities of respondents

\begin{tabular}{|l|l|l|l|l|l|l|l|l|}
\hline & $\begin{array}{l}\text { East } \\
\text { Asia }\end{array}$ & $\begin{array}{l}\text { North } \\
\text { America }\end{array}$ & $\begin{array}{l}\text { Oceania and } \\
\text { Pacific }\end{array}$ & $\begin{array}{l}\text { South } \\
\text { America }\end{array}$ & $\begin{array}{l}\text { South- } \\
\text { East Asia }\end{array}$ & $\begin{array}{l}\text { Africa and } \\
\text { Middle East }\end{array}$ & $\begin{array}{l}\text { Western } \\
\text { Europe }\end{array}$ \\
\hline Gender & \multicolumn{7}{|l|}{} \\
\hline Male & $40 \%$ & $37 \%$ & $24 \%$ & $37 \%$ & $38 \%$ & $63 \%$ & $23 \%$ \\
\hline Female & $58 \%$ & $63 \%$ & $75 \%$ & $63 \%$ & $60 \%$ & $37 \%$ & $76 \%$ \\
\hline Age & & & & & & & \\
\hline$<25$ & $24 \%$ & $5 \%$ & $4 \%$ & $39 \%$ & $15 \%$ & $5 \%$ & $23 \%$ \\
\hline $\mathbf{2 5 - 3 4}$ & $39 \%$ & $37 \%$ & $22 \%$ & $18 \%$ & $28 \%$ & $40 \%$ & $41 \%$ \\
\hline $\mathbf{3 5 - 4 4}$ & $18 \%$ & $15 \%$ & $25 \%$ & $23 \%$ & $21 \%$ & $31 \%$ & $14 \%$ \\
\hline $\mathbf{4 5 - 5 4}$ & $10 \%$ & $15 \%$ & $29 \%$ & $12 \%$ & $20 \%$ & $17 \%$ & $14 \%$ \\
\hline $55-64$ & $9 \%$ & $17 \%$ & $14 \%$ & $7 \%$ & $12 \%$ & $7 \%$ & $5 \%$ \\
\hline$>65$ & $1 \%$ & $12 \%$ & $5 \%$ & $1 \%$ & $4 \%$ & $1 \%$ & $3 \%$ \\
\hline
\end{tabular}

15 The Cronbach's alpha value for the six items, described below, is shown to be 0.492 , while the cut-off value of 0.7 is usually used in social science research and is generally considered reliable. If we re-run the overall steps by removing the first variable (willingness to travel) the Cronbach's alpha value increases to 0.618. However, Cronbach's alpha should not be used as sole criteria for measuring reliability. 


\section{Willingness to travel}

When asked about the likelihood of changing behaviour after Covid, respondents from China were the only group for which the average rating of responses was neutral (3.07). For the other nationality groups, it is very likely, if not certain, that most will not change their behaviour. In other words, most do not wish to change their behaviour. In average, about $20 \%$ only disagree or totally disagree with the idea of an absence of impact of Covid on their propensity to travel, and consider they won't continue to travel as they did before.

Figure 1. I don't think I will change my behaviour and I wish I could continue to travel as before

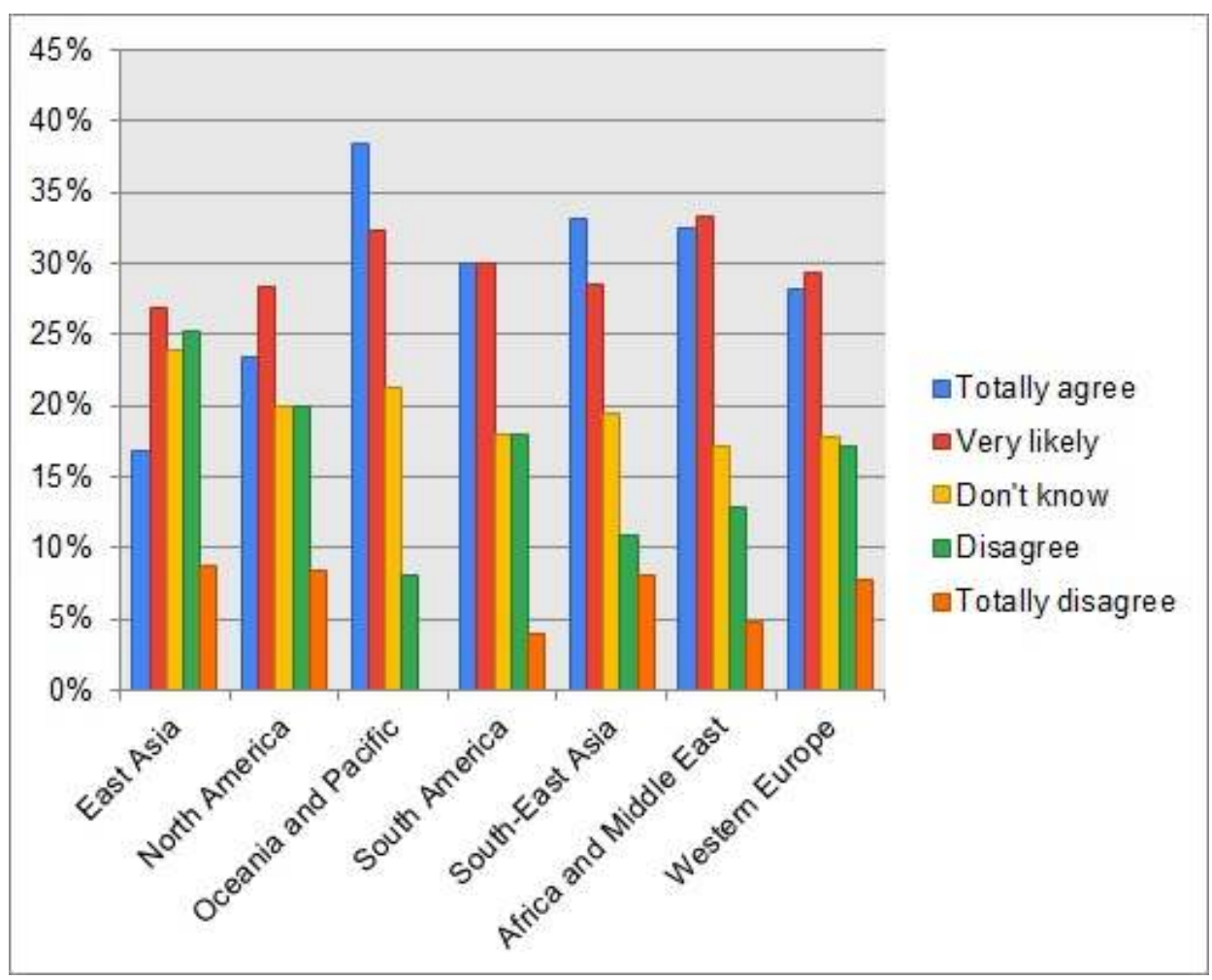

17 From the output of the non-parametric test, the median of the willingness to travel doesn't vary between genders and categories of age with $p$ values greater than 0.05 ( 0.381 and 0.108 ) but we reject the null hypothesis for the classification of the origin of respondents for which the medians strongly vary $(p$ value $=0.000)$ across categories. The contingency table of medians between the different origins of respondents below confirms this result and the observation made in the above diagram.

Table 3. Contingency table for willingness to travel by origin of respondents

\begin{tabular}{|l|l|l|l|l|l|l|l|}
\hline & $\begin{array}{l}\text { East } \\
\text { Asia }\end{array}$ & Europe & $\begin{array}{l}\text { Middle East } \\
\text { Africa }\end{array}$ & $\begin{array}{l}\text { South } \\
\text { America }\end{array}$ & $\begin{array}{l}\text { North } \\
\text { America }\end{array}$ & $\begin{array}{l}\text { Oceania and } \\
\text { Pacific }\end{array}$ & $\begin{array}{l}\text { South } \\
\text { East-Asia }\end{array}$ \\
\hline$>$ Median & 54 & 217 & 68 & 32 & 14 & 38 & 59 \\
\hline & $17 \%$ & $27 \%$ & $33 \%$ & $31 \%$ & $23 \%$ & $38 \%$ & $33 \%$ \\
\hline
\end{tabular}




\begin{tabular}{|l|l|l|l|l|l|l|l|}
\hline <= Median & 262 & 577 & 141 & 72 & 46 & 61 & 122 \\
\hline & $83 \%$ & $73 \%$ & $67 \%$ & $69 \%$ & $77 \%$ & $62 \%$ & $67 \%$ \\
\hline
\end{tabular}

\section{Ability to travel}

Mainly for respondents from Iran (3.54) and South America (3.73), and to a lesser extent to Africa and the Middle East (3.39), it is most likely that their financial situation will not allow them to travel. For respondents from Asia, Oceania and the Pacific, this is still uncertain, while Westerners (Europeans - 2.72 and North Americans - 2.50) seem quite confident that they won't be constrained by their financial situation. Note that we are on younger samples of respondents for the latter.

Figure 2. I am afraid that my financial situation as a result of this health crisis will not allow me to travel for at least a year

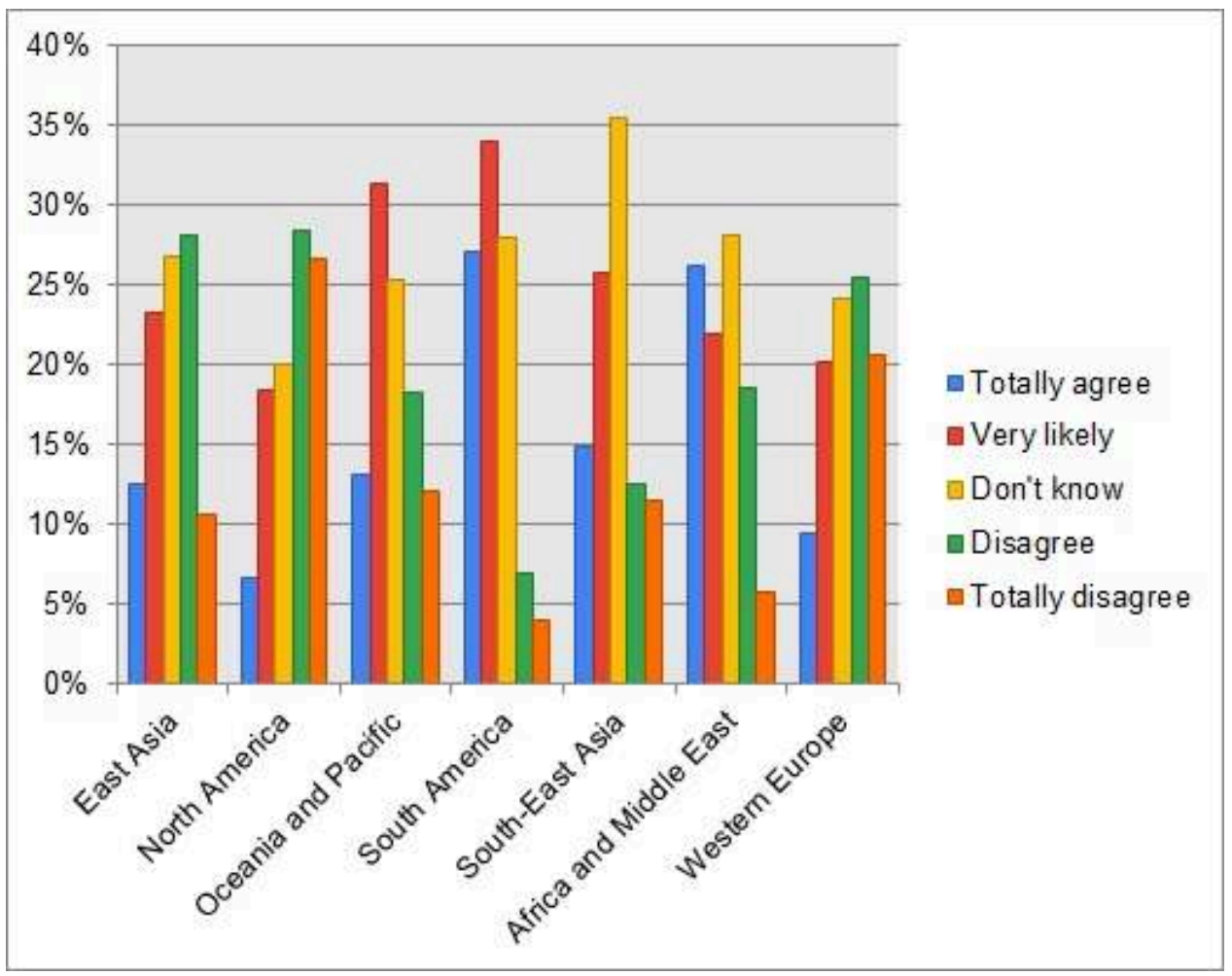

With regards to the ability to travel, the medians are again the same across the categories of gender and age with $\mathrm{p}$ values greater than 0.05 (0.249 and 0.198) but we reject again the null hypothesis for the regions of origin $(p=0.000)$, i.e., we observe strong differences between medians across groups. The contingency table confirms the results obtained in analysing the above diagram.

Table 4. Contingency table for ability to travel by origin of respondents

\begin{tabular}{|l|l|l|l|l|l|l|l|}
\hline & $\begin{array}{l}\text { East } \\
\text { Asia }\end{array}$ & Europe & $\begin{array}{l}\text { Middle East } \\
\text { Africa }\end{array}$ & $\begin{array}{l}\text { South } \\
\text { America }\end{array}$ & $\begin{array}{l}\text { North } \\
\text { America }\end{array}$ & $\begin{array}{l}\text { Oceania and } \\
\text { Pacific }\end{array}$ & $\begin{array}{l}\text { South } \\
\text { East-Asia }\end{array}$ \\
\hline
\end{tabular}




\begin{tabular}{|l|l|l|l|l|l|l|l|}
\hline > Median & 111 & 236 & 100 & 62 & 15 & 44 & 74 \\
\hline & $35 \%$ & $30 \%$ & $48 \%$ & $60 \%$ & $25 \%$ & $44 \%$ & $41 \%$ \\
\hline <= Median & 205 & 558 & 109 & 42 & 45 & 55 & 107 \\
\hline & $65 \%$ & $70 \%$ & $52 \%$ & $40 \%$ & $75 \%$ & $56 \%$ & $59 \%$ \\
\hline
\end{tabular}

\section{Distance of travel in the context of a health crisis}

With an average greater than 3, all nationality groups think that their trips will initially be less far from their country of origin, with priority given to their country of residence or border countries. Differences are only observed in the degree of certainty with, in particular, a higher degree of certainty for Iranians and South Americans. But these differences in medians are statistically significant, as observed in the results of the non-parametric tests with a $p$ value smaller than $0.05(p=0.000)$. However, no significant differences in medians are observed across gender and age categories $(0.373$ and 0.783).

Figure 3. I believe that my travels will initially be less far from my home country with priority for my country of residence or border countries

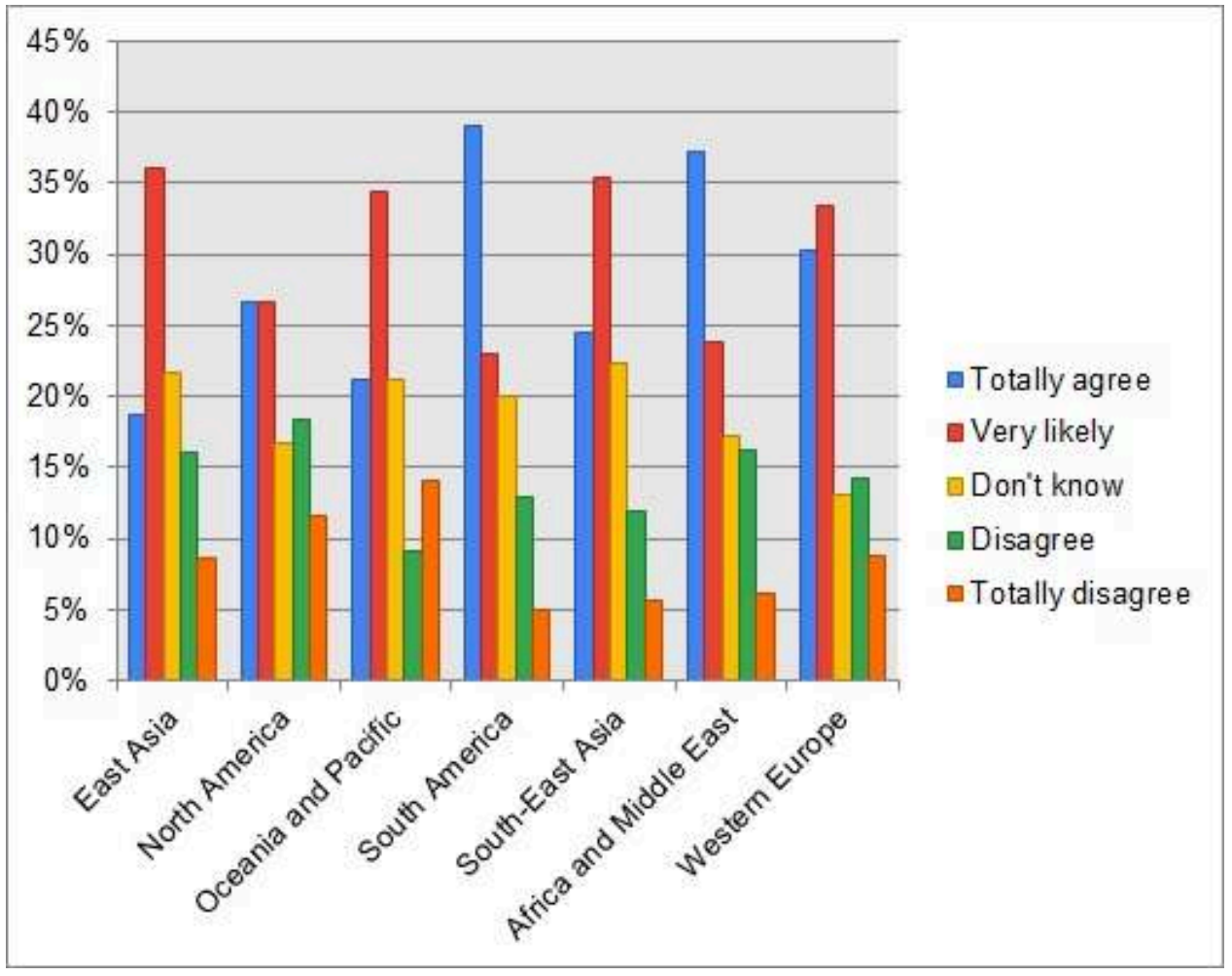

Table 5. Contingency table for distance to travel after Covid by origin of respondents

\begin{tabular}{|l|l|l|l|l|l|l|l|}
\hline & $\begin{array}{l}\text { East } \\
\text { Asia }\end{array}$ & Europe & $\begin{array}{l}\text { Middle East } \\
\text { Africa }\end{array}$ & $\begin{array}{l}\text { South } \\
\text { America }\end{array}$ & $\begin{array}{l}\text { North } \\
\text { America }\end{array}$ & $\begin{array}{l}\text { Oceania and } \\
\text { Pacific }\end{array}$ & $\begin{array}{l}\text { South } \\
\text { East-Asia }\end{array}$ \\
\hline
\end{tabular}




\begin{tabular}{|l|l|l|l|l|l|l|l|}
\hline > Median & 58 & 229 & 77 & 40 & 16 & 21 & 44 \\
\hline & $18 \%$ & $29 \%$ & $37 \%$ & $38 \%$ & $27 \%$ & $21 \%$ & $24 \%$ \\
\hline <= Median & 258 & 565 & 132 & 64 & 44 & 78 & 137 \\
\hline & $82 \%$ & $71 \%$ & $63 \%$ & $62 \%$ & $73 \%$ & $79 \%$ & $76 \%$ \\
\hline
\end{tabular}

\section{Desired impact of future travel}

Although all nationalities, or groups of nationalities, want a different form of tourism, more respectful of nature and the communities visited, there is a stronger conviction for sustainable tourism among groups of nationalities with younger respondents (South America, South-East Asia, Africa and Middle East, and Western Europe). However, this observation is less clear-cut for certain nationalities (Iran) or groups of nationalities (Oceania and the Pacific) for which there are either uncertainties or divergences of the same proportion as the certainties about this ambition.

Figure 4. I would like a different form of tourism, more respectful of the visited communities and of nature

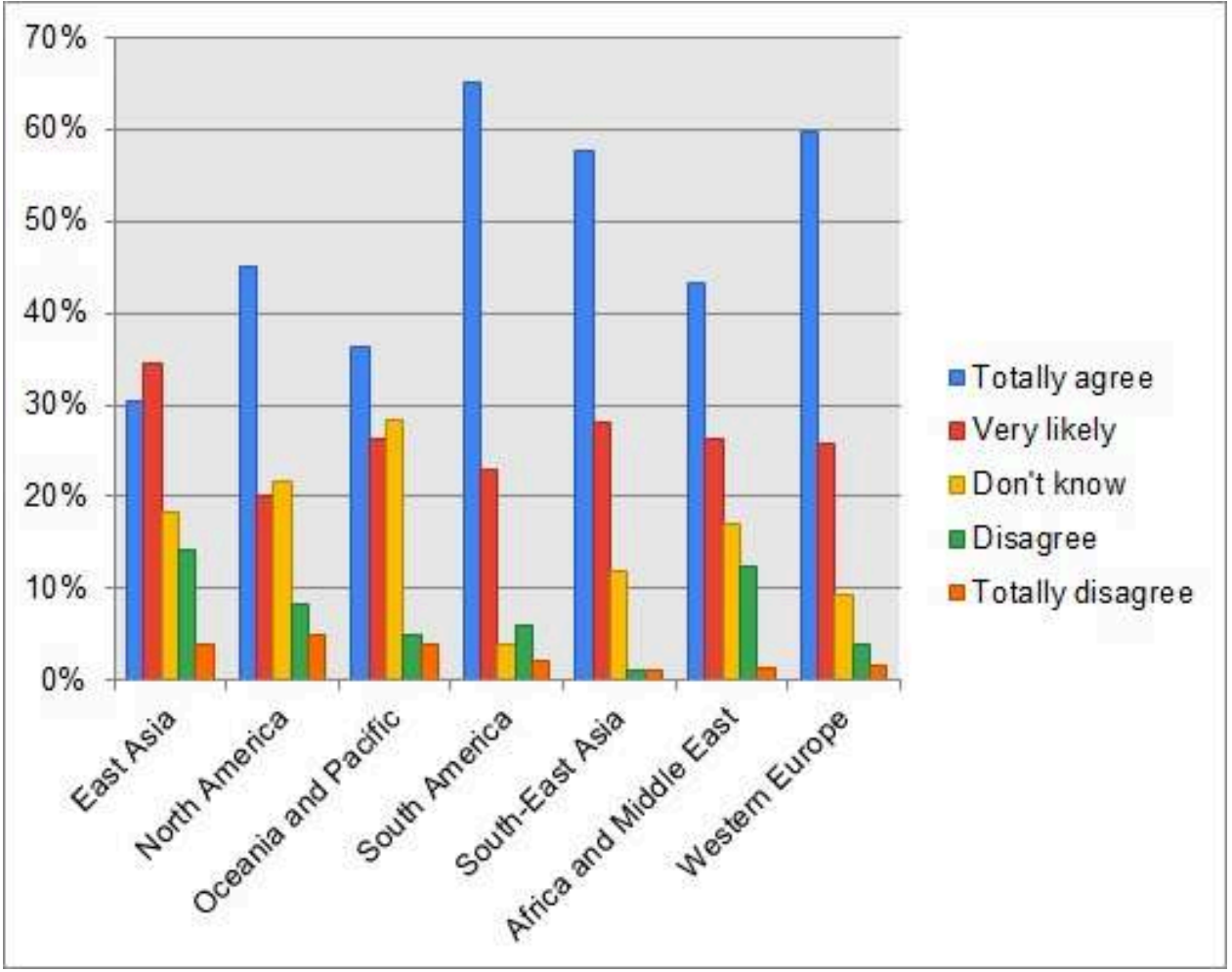

The statistical analysis of the results confirms that the differences of medians are statistically significant across age brackets $(p=0.005)$ and the origin of respondents $(p=0.000)$. However, no differences were observed across gender categories $(p=0.072)$. The observations made in the diagram are confirmed in the contingency table, in which we observed that the group of countries, for which respondents are younger, is more likely to experience a different form of tourism. 
Table 6. Contingency table for the desired impact of future travel by origin of respondents

\begin{tabular}{|l|l|l|l|l|l|l|l|}
\hline & $\begin{array}{l}\text { East } \\
\text { Asia }\end{array}$ & Europe & $\begin{array}{l}\text { Middle East } \\
\text { Africa }\end{array}$ & $\begin{array}{l}\text { South } \\
\text { America }\end{array}$ & $\begin{array}{l}\text { North } \\
\text { America }\end{array}$ & $\begin{array}{l}\text { Oceania and } \\
\text { Pacific }\end{array}$ & $\begin{array}{l}\text { South } \\
\text { East-Asia }\end{array}$ \\
\hline > Median & 96 & 453 & 89 & 69 & 27 & 36 & 105 \\
\hline & $30 \%$ & $57 \%$ & $43 \%$ & $66 \%$ & $45 \%$ & $36 \%$ & $58 \%$ \\
\hline$<=$ Median & 220 & 341 & 120 & 35 & 33 & 63 & 76 \\
\hline & $70 \%$ & $43 \%$ & $57 \%$ & $34 \%$ & $55 \%$ & $64 \%$ & $42 \%$ \\
\hline
\end{tabular}

\section{Type of destinations visited}

With the exception of the groups of nationalities from East Asia and Oceania and the Pacific, on average older than the others, for whom the intention to continue travelling to mass tourism destinations or major cities remains uncertain but still exists, the other groups of nationalities seem to want to avoid these destinations.

Figure 5. I now wish to avoid mass tourism destinations and large cities

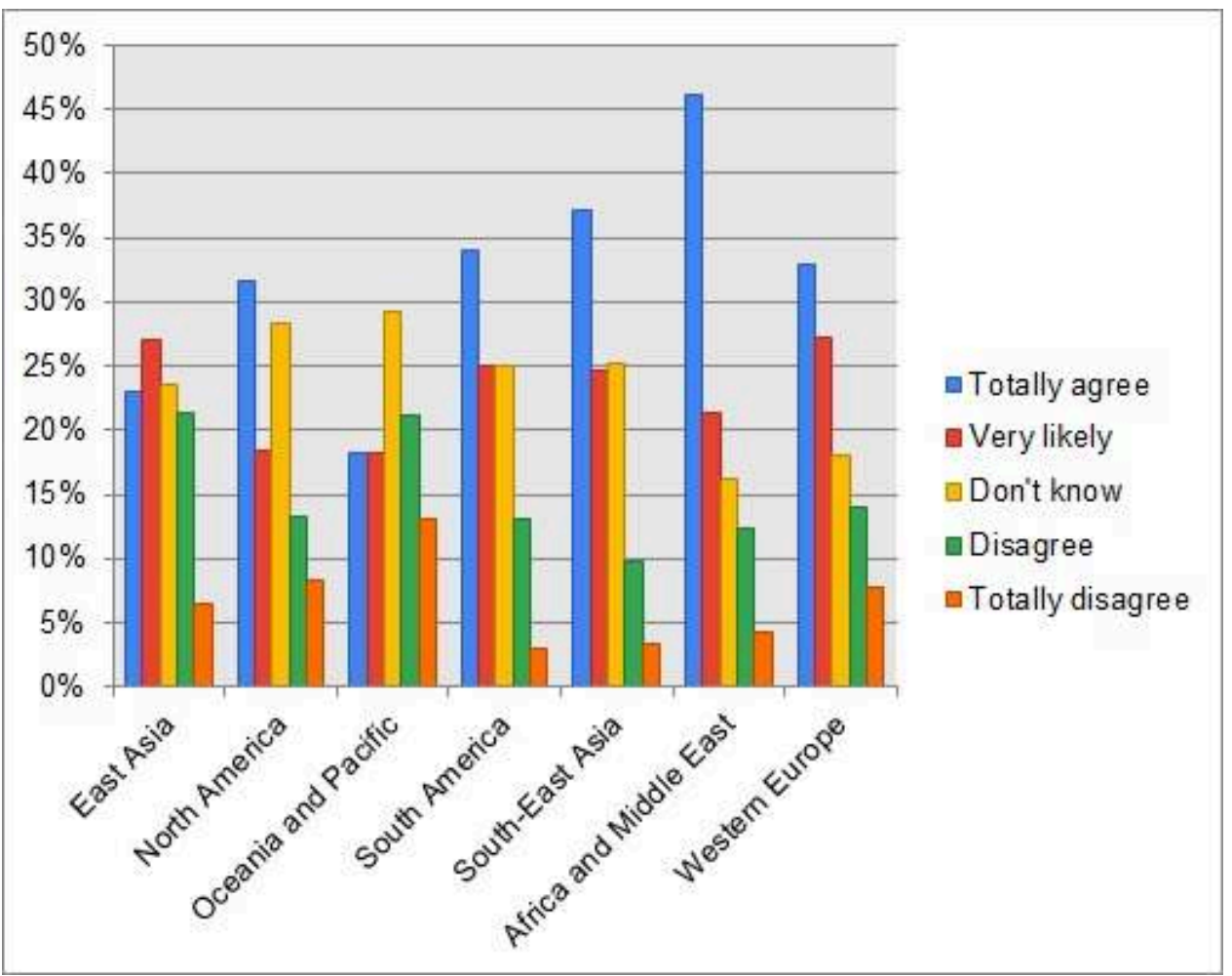

For the type of destination to be visited, we also reject the null hypothesis for two categories as we observed significant statistical differences across both the age and origin groups ( $\mathrm{p}=0.026$ and $\mathrm{p}=0.000$ ). The contingency table below by age group clearly 
shows that the older the respondents are, the greater the certainty is that they will continue to travel to mass tourism destinations and/or large cities.

Table 7. Contingency table for types of destinations visited by age groups

\begin{tabular}{|l|l|l|l|l|l|l|}
\hline & $<\mathbf{2 5}$ & $\mathbf{2 5 - 3 4}$ & $\mathbf{3 5 - 4 4}$ & $\mathbf{4 5 - 5 4}$ & $\mathbf{5 5 - 6 4}$ & $>\mathbf{6 5}$ \\
\hline > Median & 87 & 188 & 116 & 105 & 54 & 19 \\
\hline & $27 \%$ & $30 \%$ & $34 \%$ & $38 \%$ & $38 \%$ & $40 \%$ \\
\hline <= Median & 241 & 439 & 226 & 172 & 88 & 28 \\
\hline & $73 \%$ & $70 \%$ & $66 \%$ & $62 \%$ & $62 \%$ & $60 \%$ \\
\hline
\end{tabular}

\section{Perception of destinations internationally in terms of health risks}

From a health perspective, the different nationality groups perceive very differently the idea that some destinations would now be more at risk than others. Respondents of Iranian, Chinese and African or Middle East nationalities have a stronger propensity to view this assumption positively, in contrast to Western Europeans, for whom this is not the case. It is difficult to consider age as an explanatory factor, since both the Chinese and the Western European samples of respondents are made up mostly of individuals below the age of 34 .

Figure 6. I now believe that certain countries and regions are at risk from a health point of view and I no longer wish to visit them

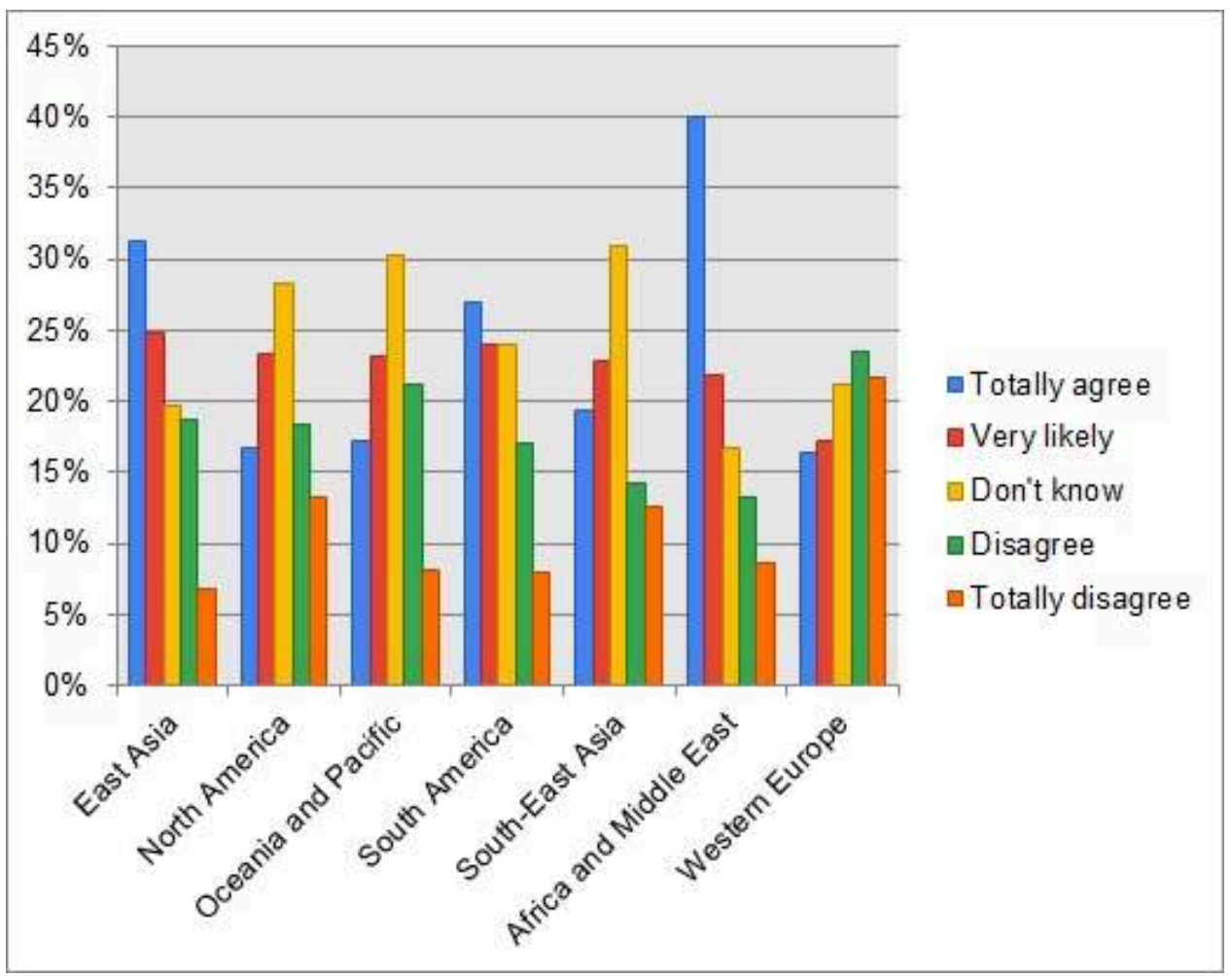


However, the statistical analysis of the results highlights that the age $(\mathrm{p}=0.026)$ and the origin of respondents $(\mathrm{p}=0.000)$ are playing an important role in the perception of some destinations in terms of health risks, contrarily to the gender categories $(\mathrm{p}=0.193)$. The differences in the medians between the age categories are mainly observed for the "45-64 years" age group compared to the others, an age group for which there is rather a strong adhesion to the idea of a "country risk" compared to the other categories.

Table 8. Contingency table for the perception of destinations being at risk by age groups

\begin{tabular}{|l|l|l|l|l|l|l|}
\hline & $<\mathbf{2 5}$ & $\mathbf{2 5 - 3 4}$ & $\mathbf{3 5 - 4 4}$ & $\mathbf{4 5 - 5 4}$ & $\mathbf{5 5 - 6 4}$ & $>\mathbf{6 5}$ \\
\hline > Median & 125 & 267 & 155 & 148 & 60 & 20 \\
\hline & $38 \%$ & $43 \%$ & $45 \%$ & $53 \%$ & $42 \%$ & $43 \%$ \\
\hline <= Median & 203 & 360 & 187 & 129 & 82 & 27 \\
\hline & $62 \%$ & $57 \%$ & $55 \%$ & $47 \%$ & $58 \%$ & $57 \%$ \\
\hline
\end{tabular}

Although for $13 \%$ of the respondents, no destination seems safe today, three regions are however considered by about a third of the respondents as safe from a health perspective, namely Northern Europe (31\%), East Asia (27\%) and Oceania and Pacific (26\%).

Figure 7. Which countries or regions now seem to you to be the safest from a health perspective?

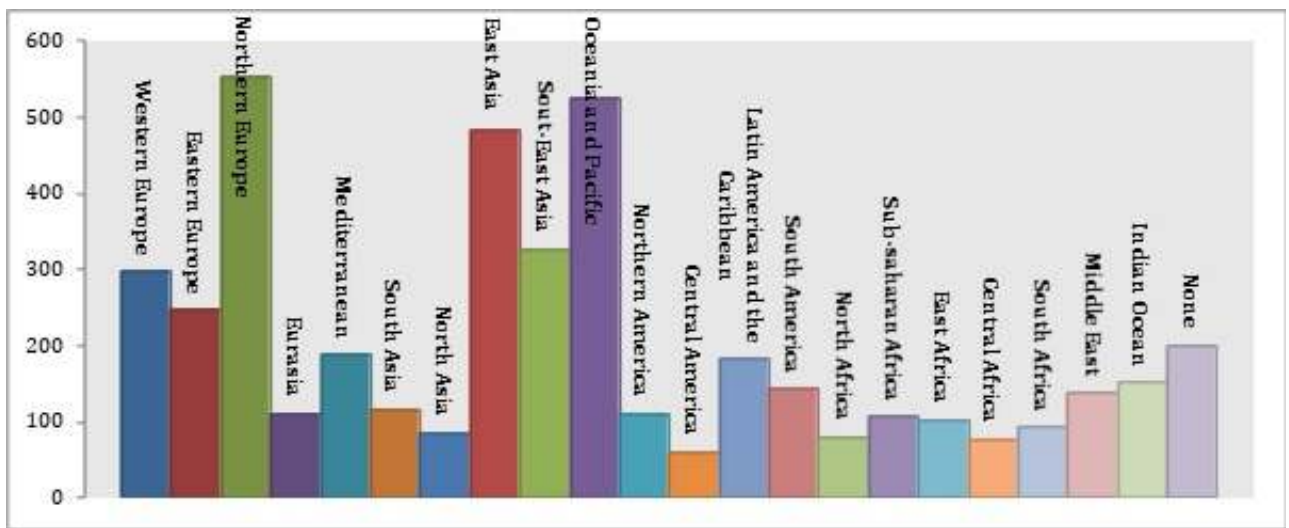

The question concerning the least safe countries/regions from a health perspective, in view of the current crisis, also reveals a group of three regions, of which two had the highest number of cases at the time of the questionnaire (Northern America - 39\% and Western Europe - 29\%). Paradoxically, East Asia, which was considered as one of the safest regions by $27 \%$ of respondents, is also considered as one of the least safe by $32 \%$ of respondents. This is due in part to the origin of the respondents and the geographic origin of the pandemic. 
Figure 8. Which countries or regions now seem to you to be the least safe from a health perspective?

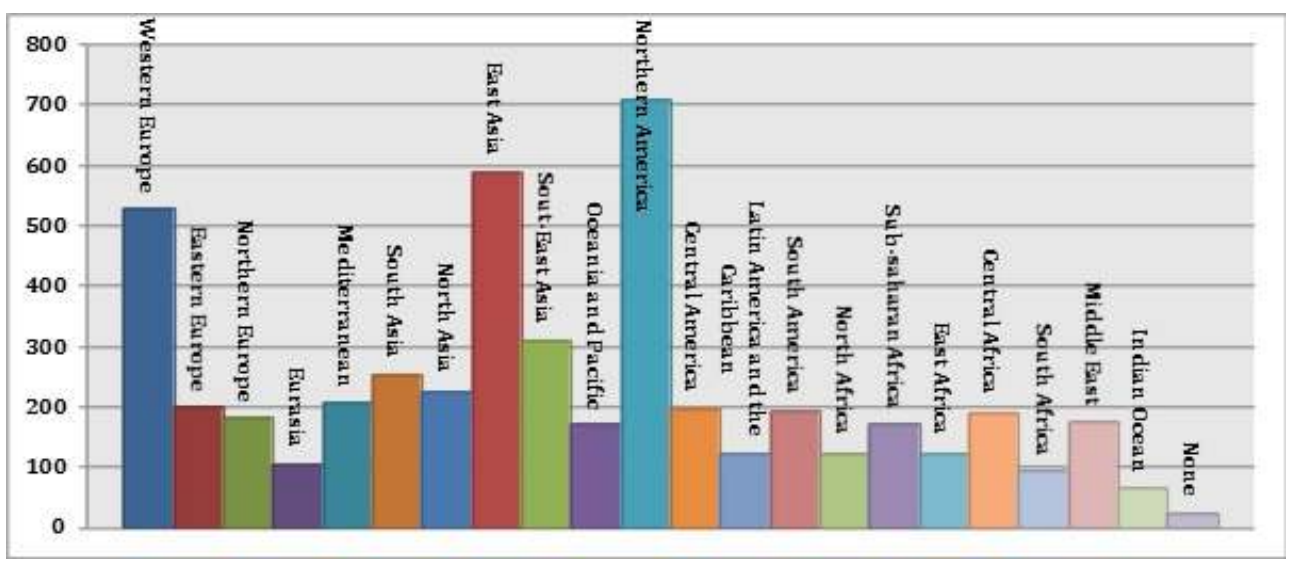

\section{Discussion}

For many respondents, there is still a great deal of uncertainty regarding their financial capacity to travel in the coming year (Median $=3$ ), even though for a large proportion of them, the desire not to change their behaviour remains the majority (Median $=4$ ). This result is surprising because they are constrained by government decisions (travel restrictions, travel bubbles, etc.) and, paradoxically, many of them would like to see a new form of tourism (Median $=4$ ) that is more respectful of the communities visited and of nature. The age and geographical areas of the respondents, rather than their nationality, mainly influence the responses. It also seems that respondents from Northern countries are more confident about their financial capacity for the coming years than those from emerging economies. Is this a sign of overconfidence in the ability of governments and international institutions to mitigate the impacts of the crisis?

However, the consequences of the crisis, and especially the way it was managed by governments, differs from country to country, with strong differences between regions of the world, and more specifically within those regions that saw a limited financial impact of the crisis on their revenues in the early beginning of the pandemic. At the time of the study (May 2020), there was a strong correlation between the number of cases in a country and its perception as a destination to avoid. For example, American and European destinations, the most affected by Covid- 19 in that period, are cited by a majority of respondents as being at high risk. The same is true for mass tourism destinations and large cities, except for respondents from Asia-Pacific, a region less affected by the pandemic. The future trend would be towards wide-open spaces, but the contradiction between some of the responses also reflects the possibility that current emotions may have interfered with the assessment. It is already apparent that responses to questionnaires set up in times of crisis or uncertainty do suffer from what is known as social desirability bias or affective bias: people often avoid selecting the extreme items or disagreeing with statements to seem more "normal" or show themselves in a favourable light.

Ultimately, the current situation and the observation of post-decommissioning behaviours allow us to conclude that these are dependent on the restrictions, but once 
these restrictions are lifted, there are no fundamental changes with regard to the issues raised. The question is therefore whether the pandemic has really changed anything in people's behaviour? If not, will destinations simply resume their race for attractiveness and quantitative targets? While this study was conducted in June 2020 , the pandemic is still on-going. It would therefore be necessary to repeat this research, assuming that the social desirability bias would now be reduced, respondents are now largely vaccinated, and their perception of risk destinations is different.

\section{BIBLIOGRAPHY}

Xiaojing CAI, Caroline V. FRY and Caroline S. WAGNER, "International Collaboration during the Covid-19 Crisis: Autumn 2020 Developments", Scientometrics, n 126, p. 3683-3692, 2021 [https:// doi.org/10.1007/s11192-021-03873-7].

Luis-Alberto CASADO-ARANDA, Juan SÁNCHEZ-FERNÁNDEZ and Ana-Belén BASTIDAS-MANZANO, “Tourism Research after the Covid-19 Outbreak: Insights for More Sustainable, Local and Smart Cities”, Sustainable Cities and Society, vol. 73, 2021 [https://doi.org/10.1016/j.scs.2021.103126].

Malcom COOPER, "Japanese Tourism and the SARS Epidemic of 2003", Journal of Travel \& Tourism Marketing, vol. 19, n² 2-3, p. 117-131, 2006 [https://doi.org/10.1300/J073v19n02_10].

Inmaculada GALLEGo and Xavier FonT, "Changes in Air Passenger Demand as a Result of the Covid-19 Crisis: Using Big Data to Inform Tourism Policy”, Journal of Sustainable Tourism, vol. 29, $\mathrm{n}^{\circ}$ 9, p. 1470-1489, 2021 [https://doi.org/10.1080/09669582.2020.1773476].

Maksim GODOVYKH, Abraham PIZAM and Frida BAHJA, "Antecedents and Outcomes of Health Risk Perceptions in Tourism, following the Covid-19 Pandemic”, Tourism Review, vol. 76, n 4, 2021.

Anne GOMBAUlT, Jérémy LEMARIE and Claire GRELLIER FOUILLET, “La crise du COVID-19, un changement stratégique pour le tourisme? L'analyse de la recherche internationale”, Espaces, vol. 355, 2020, p. 79-85

Anne Gombault, “Tourisme post-Covid-19 : l'agenda de recherche”, Espaces, n 358, 2021.

Stefan GössLING, Daniel scotT and C. Michael HALL, "Pandemics, Tourism and Global Change: A Rapid Assessment of Covid-19”, Journal of Sustainable Tourism, vol. 29, n 1, p. 1-20, 2021 [https:// doi.org/10.1080/09669582.2020.1758708].

Feng HU, Thorsten TEICHERT, Shengli DENG, Yong LIU and Guotao ZHOU, "Dealing with Pandemics: An Investigation of the Effects of Covid-19 on Customers' Evaluations of Hospitality Services", Tourism Management, $\mathrm{n}^{\circ}$ 85, 2021 [https://doi.org/10.1016/j.tourman.2021.104320].

Dimitri IOANNIDES and Szilvia GYIMÓTHY, "The Covid-19 Crisis as an Opportunity for Escaping the Unsustainable Global Tourism Path", Tourism Geographies, vol. 22, n 3, p. 624-632, 2020 [https:// doi.org/10.1080/14616688.2020.1763445].

Edward кон, “The End of Over-tourism? Opportunities in a Post-Covid-19 World”, International Journal of Tourism Cities, vol. 6, n 4, p. 1015-1023, 2020. 
Ivan Kožić, Josip MIKULIĆ and Damir KREŠÍ́, "Propensity to Travel: What Is the Macro-Data Telling Us?", in Álvaro Matias, Peter Nijkamp and João Romão (eds), Impact Assessment in Tourism Economics, Springer, 2016 [https://doi.org/10.1007/978-3-319-14920-2_2].

Simon MAIR, "What Will the World Be Like after the Coronavirus? Four Possible Futures", The conversation, 2020 [https://theconversation.com/what-will-the-world-be-like-aftercoronavirus-four-possible-futures-134085].

Marianna SIGALA, “Tourism and Covid-19: Impacts and Implications for Advancing and Resetting Industry and Research", Journal of Business Research, vol. 117, p. 312-321, 2020 [https://dx.doi.org/ 10.1016\%2Fj.jbusres.2020.06.015].

TOURISM REVIEW, “Vaccination gap seriously impacts global tourism”, 2021 [https://www.tourismreview.com/recovery-of-global-tourism-prevented-by-vaccination-gap-news12221].

Naciye Güliz UĞUR and Adem AKBIYIK, "Impacts of Covid-19 on Global Tourism Industry: A Crossregional Comparison", Tourism Management Perspectives, vol. 36, 2020 [https://dx.doi.org/ 10.1016\%2Fj.tmp.2020.100744].

Jun WEN, Wei WANG, Metin KozAK, Xinyi LIU and Haifeng Hou, "Many Brains Are Better Than One: The Importance of Interdisciplinary Studies On Covid-19 In and Beyond Tourism", Tourism Recreation Research, vol. 0(0), p. 1-4, 2020.

Yang YANG, Carol X. ZHANG and Jillian M. RICKLY, “A Review of Early Covid-19 Research in Tourism: Launching the Annals of Tourism Research's Curated Collection on Coronavirus and Tourism", Annals of Tourism Research, n 91, 2021 [https://doi.org/10.1016/j.annals.2021.103313].

Sejfudin ZAHIROvIĆ, Jasmina OKIČIć, Mensur HERIĆ and Dino KAKEŠ, "Likelihood of Propensity to Travel: Prediction based on Socio-demographic Factors", Hotel and Tourism Management, vol. 9, n 1, p. 61-71, 2021 [https://doi.org/10.5937/menhottur2101061Z].

\section{NOTES}

1. The author would like to thank Christine Jacquemin of the RTA (www.be-rta.com) and former students of IREST, University Paris 1 Panthéon-Sorbonne, for their help in translating and disseminating the questionnaire in their networks (Youra Choi, Luis Alenjandro Davila, Haimin Lin et Xi Zhao, Sydney To, Phuong Nhung Cao, Tourkia Maatoug, Afrooz Shafiei, Greta Livia Rapp, Anna Katebelona).

\section{AUTHOR}

\section{FRÉDÉRIC THOMAS}

EIREST, University Paris 1 Panthéon-Sorbonne

Frederic.Thomas1[at]univ-paris1.fr 